\title{
A Rare Occurrence of Plasma Cell Myeloma with Biclonal Gammopathy
}

\author{
MARDZIAH $M^{1,2}$, NURASYIKIN $\mathrm{Y}^{1,2}$, RAFEAH T ${ }^{3}$, DIAN N ${ }^{1,2}$, \\ YOUSUF $R^{1,2}$, SURIA AA ${ }^{1,2}$ \\ Departments of ${ }^{1}$ Diagnostic and Laboratory Services, ${ }^{2}$ Pathology and ${ }^{3}$ Medicine, Faculty \\ of Medicine, Universiti Kebangsaan Malaysia Medical Centre, Jalan Yaacob Latif, Bandar \\ Tun Razak, 56000 Cheras, Kuala Lumpur, Malaysia.
}

\begin{abstract}
ABSTRAK
Myeloma sel plasma telah diketahui menyebabkan pengeluaran immunoglobulin (Ig) monoklonal yang mengakibatkan rembesan protein monoklonal homogenus (komponen M) yang unik. Walaubagaimanapun, terdapat kes-kes melaporkan bahawa ia juga boleh menyebabkan pengeluaran dua klon protein M monoklonal yang berbeza. Walaupun ia agak jarang berlaku dan hanya 2\% kes direkodkan daripada semua kes myeloma sel plasma, ciri-ciri klinikal adalah sama dengan manamana kes monoklonal tersebut. Berkemungkinan 2 klon protein $M$ yang berbeza ini adalah hasil daripada klon yang sama atau dua klon sel monoklonal yang berbeza. Walau apa pun mekanisme penyakit ini, tindak-balas terhadap rawatan adalah sama dengan kes-kes monoklonal walaupun beberapa laporan menunjukkan rintangan terhadap rawatan boleh berlaku. Di sini, kami melaporkan satu kes myeloma sel plasma yang jarang direkodkan dimana kes ini menunjukkan penghasilan dua klon protein $M$ yang berbeza iaitu IgG (lambda) dan IgA (lambda), ciri-ciri klinikal, ciriciri hematologi serta penanda biokimia dan tindak balas kepada rawatan.
\end{abstract}

Kata kunci: gamopati dwiklonal, protein M, myeloma sel plasma

\begin{abstract}
Plasma cell myeloma is known to cause expansion of a single clone of immunoglobulin (Ig) which results in the secretion of a unique homogeneous monoclonal protein ( $\mathrm{M}$ component). However, there are cases which reported that it can also cause production of two different clones of these monoclonal $\mathrm{M}$ proteins. Although it is relatively very rare as the prevalence is only $2 \%$ of all plasma cell myeloma cases, the clinical features are said to be similar to monoclonal gammopathy. It is suggested that these biclonal gammopathy results from either one monoclonal cell clone in monoclonal gammopathy or two different
\end{abstract}

Address for correspondence and reprint requests: Suria Abdul Aziz, Department of Pathology, Faculty of Medicine, Universiti Kebangsaan Malaysia Medical Centre, Jalan Yaacob Latif, Bandar Tun Razak, 56000 Cheras, Kuala Lumpur, Malaysia. Tel: 603-91455443 Fax: 603-91456676 E-mail: suria.abdulaziz@gmail.com 
monoclonal cell clones. Whichever the mechanism of the disease be, the response to treatment seems to be similar as compared to the monoclonal cases although some reports shows chemoresistant. Here, we report a rare case of plasma cell myeloma with IgG (lambda) and IgA (lambda) type of biclonal gammopathy, the clinical presentation, the haematological and biochemical markers as well as the response to the treatment.

Keywords: biclonal gammopathy, M protein, plasma cell myeloma

\section{INTRODUCTION}

Plasma cell myeloma is a neoplastic clonal disease associated with plasma cell infiltration in the medullary space. It causes clonal proliferations of immunoglobulin detectable as monoclonal protein peak or M-protein on serum or urine protein electrophoresis studies. This condition is also known as monoclonal gammopathy and the proteins are mostly IgG M-protein type in more than $50 \%$ of cases and $\lg \mathrm{A}$ in $20 \%$ of cases (Swerdlow et al. 2008). Monoclonal gammopathy can also produce only monoclonal light chains in $20 \%$ of cases (Swerdlow et al. 2008) and fewer than $2 \%$ of cases produce monoclonal IgD, IgE, or IgM (Reece et al. 2010).

Biclonal gammopathies are rare group of disorders characterized by simultaneous production of two distinct monoclonal proteins. These two distinct monoclonal proteins can be the result of proliferation of two clones of plasma cells, each producing a different monoclonal immunoglobulin, or it may be due to the production of two monoclonal proteins by a single clone of plasma cells (Kyle et al. 1981). The most common combination of these biclonal gammopathies are $\lg \mathrm{G}$ and $\lg \mathrm{A}(53 \%)$, followed by $\lg \mathrm{M}$ and IgG combination (24\%) (Kyle et al. 1981). Other reports have described combinations of biclonal gammopathies, including IgD/lgG, $\lg \mathrm{G} / \lg M, \lg \mathrm{A} / \operatorname{lgG}$, and kappa/lambda light chain biclonal gammopathies (Huppmann et al. 2010; Kim et al. 2011). The clinical presentations and the response to therapy in such cases is said to be similar to monoclonal gammopathy type of plasma cell myeloma.

Here, we report a rare case of plasma cell myeloma with IgG (lambda) and IgA (lambda) type of biclonal gammopathy detected by appearance of two bands in the lambda region on serum protein electrophoresis. The classes were further confirmed by immunofixation. We present our data to disseminate knowledge on this rare presentation of plasma cell myeloma.

\section{CASE REPORT}

A 76-year-old male was referred to the haematology team for unexplained persistent anaemia with reverse albumin to globulin ratio. He was otherwise asymptomatic. Physical examination was unremarkable except for pallor. 
Full blood count showed anaemia (haemoglobin count of $7.7 \mathrm{~g} / \mathrm{dL}$ ) with lymphocytosis $\left(5.6 \times 10^{9} / \mathrm{L}\right)$. The blood film exhibited hypochromic microcytic anaemia with presence of rouleaux formation (Figure 1). Bone marrow biopsy showed presence of $50 \%$ abnormal plasma cells which exhibited multinucleated forms, flameshaped plasma cells and vacuolated cytoplasm. Occasional immature forms were also present which exhibited more dispersed chromatin, low nuclear cytoplasmic (N/C) ratio with some having prominent nucleoli (Figure 2). All other haematopoietic cells were markedly reduced. The trephine biopsy reported hypercellular marrow composed of malignant plasma cells that were positive to CD138 with lambda light chain restriction.

The immunophenotypic analysis of the bone marrow aspirate sample showed an abnormal cells population gated at CD38 bright with low side scatter (Figure 3). These cells expressed CD138, CD56 with lambda light chain restriction. They were negative for CD19, CD117 and CD79a which was consistent with plasma cell myeloma with aberrant expression of CD56.

Bone survey showed no lytic lesion. The biochemical parameters showed normal renal profile with no evidence of hypercalcaemia. Urinalysis showed moderate proteinuria $(2+)$ with the presence of Bence Jones protein. The serum protein electrophoresis (Figure 4a) showed biclonal paraprotein in the gamma region with paraprotein quantitation of $60.4 \mathrm{~g} / \mathrm{L}$. Urine protein electrophoresis (Sebia) also indicated similar findings of tubular proteinuria

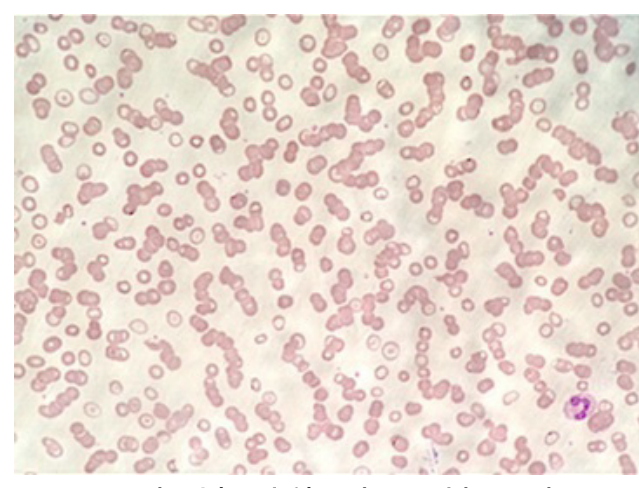

Figure 1: The blood film showed hypochromic microcytic anaemia with presence of rouleaux formation.

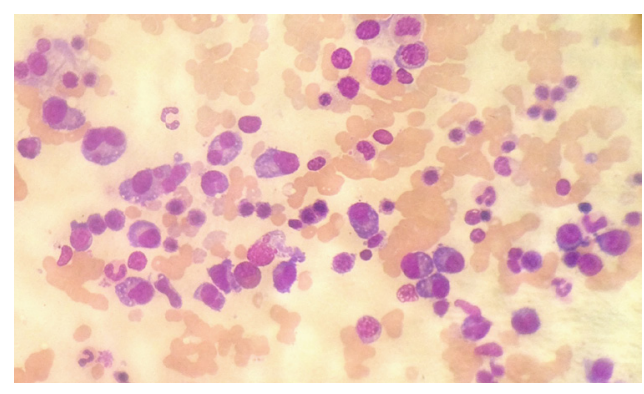

Figure 2: Bone marrow biopsy revealed a cellular marrow with presence of $50 \%$ abnormal plasma cells. The plasma cells exhibited multinucleated forms, flame-shaped plasma cells and vacuolated cytoplasm.

with the presence of Bence Jones protein with protein quantitation of $65.8 \mathrm{mg} / \mathrm{L}$. The corresponding serum immuno-fixation electrophoresis (Sebia) revealed biclonal gammopathy with the presence of two distinctly separate bands in the IgG lambda and IgA lambda region whilst the urine immuno-fixation exhibited band only in the IgG lambda region (Figure 4b).

Based on the above findings, the diagnosis of plasma cell myeloma stage II (The International Staging System) was made. The patient had been started on chemotherapy regime consisting of cyclophosphamide, thalidomide and dexamethasone but eventually 

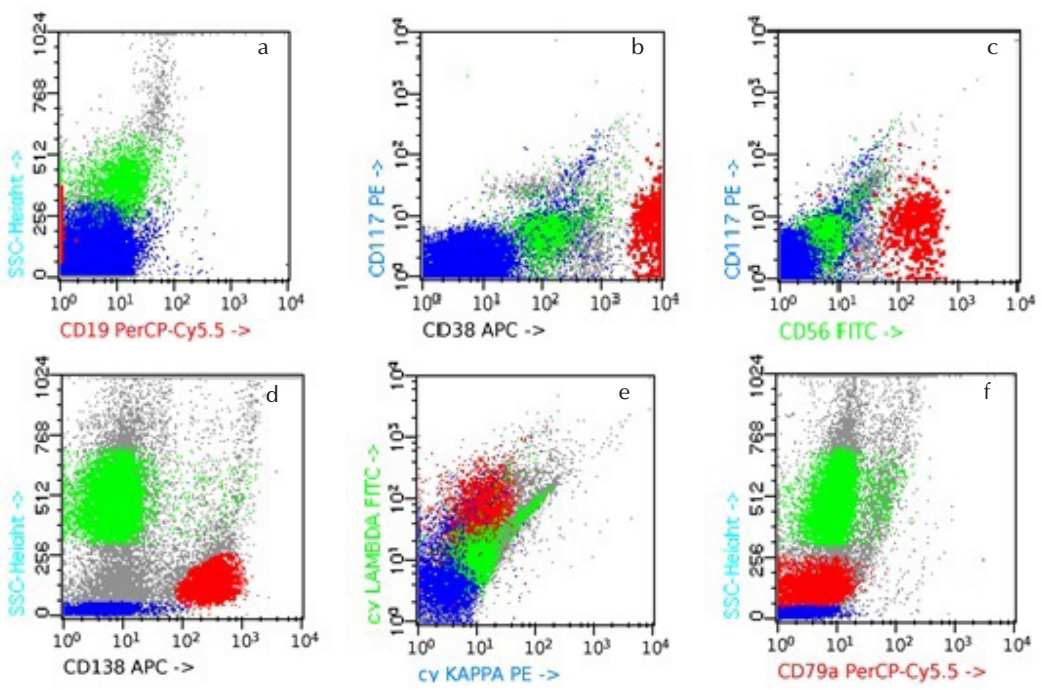

Figure 3: a-d) Flow cytometry histogram of the bone marrow aspirate showed presence of plasma cell myeloma cells depicted in red dots; e) The cells were CD38 bright and positive for CD138 and CD56. They were negative for CD19 and CD117; f) The plasma cells expressed cytoplasmic lambda light chain and negative for CD79a

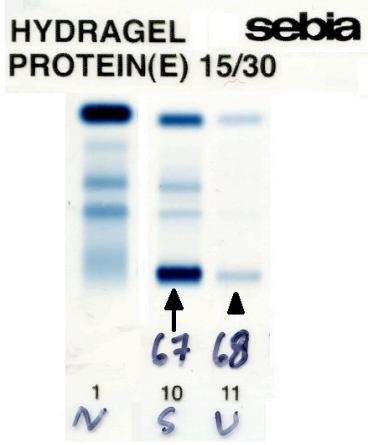

(S) $(\mathrm{U})$

(a)

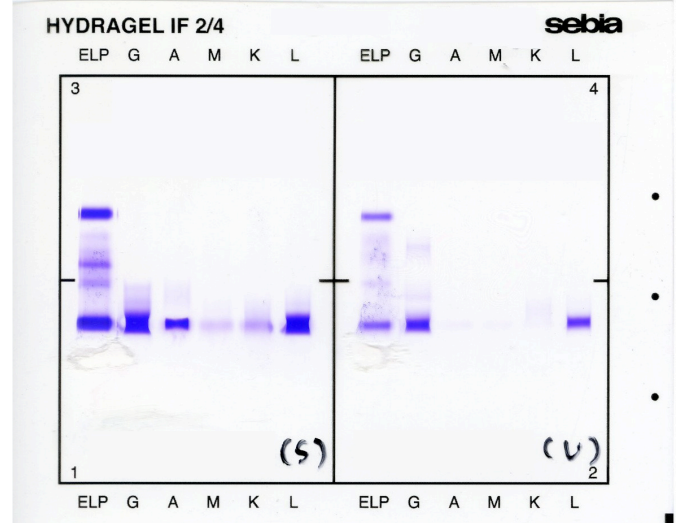

(b)

Figure 4: a) Serum (S) and urine (U) protein electrophoresis. Long arrow depicts abnormal bands in the gamma region on serum and shorter arrowhead depicts tubular proteinuria with the presence of Bence Jones protein in urine; b) Immunofixation studies showed presence of biclonal population of

$\lg$ lambda and $\lg A$ lambda in the serum sample and $\lg G$ lambda in the urine sample.

died after completed $1^{\text {st }}$ cycle due to neutropenic sepsis.

\section{DISCUSSION}

The present case highlights a rare expression of two distinct monoclonal proteins in a plasma cell myeloma patient. To the best of our knowledge, this is the first case reported in our institution. Plasma cell myeloma is characterized by heavily mutated variable region ( $\mathrm{VH}$ regions) with no intraclonal variation produced by the 
immunoglobulin. This results in clonal proliferations of plasma cells which produce monoclonal immunoglobulin heavy chain $(\mathrm{IgH})$ or monoclonal immunoglobulin light chain (IgL). However, previous studies reported up to $2 \%$ of myelomas cases which secrete two different IgH isotypes or subclasses (Kyle et al. 1981). This condition which is also called biclonal gammopathies is characterized by the production of two distinct monoclonal proteins with most being $\operatorname{lgG} / \lg \mathrm{A}(53 \%)$ or $\operatorname{lgG} / \operatorname{lgM}$ $(26 \%)$ (Kyle et al. 1981). Our patient in this case report belongs to the group of presence of two distinctly separate bands in the $\operatorname{lgG}$ lambda and $\lg \mathrm{A}$ lambda region. There are other reports showing the different combination of monoclonal proteins. Banerjee et al., (2016) reported very rare pattern of IgA with Lambda and $\lg G$ with Kappa light chains M bands. Kumar et al. (2014) has even described rarer variety of biclonal gammopathy of IgA kappa variant. Similarly other combination of biclonal IgA kappa and IgA lambda (Al-Riyami et al. 2015) were also reported.

Biclonal gammopathy can occur as a result of proliferation of two clones of plasma cells, each producing an unrelated monoclonal immunoglobulin, or it may result from production of two monoclonal proteins by a single clone of plasma cells (Kim et al. 2011). Although these biclonal gammopathies can be due to proliferation of two different clones of unrelated plasma cells and monoclonal proteins, it has been postulated that some biclonal pairs may result from a transformation event in a cell undergoing a variable region switch from one heavy chain class or subclass to another. If this was the case, it would be predicted that the variable regions of the biclonal pair would be identical and it might be possible to find some plasma cells producing both monoclonal proteins (Kyle et al. 1981).

Plasma cell myeloma with monoclonal $\lg G$ subtype has been shown to have clonotypic $\mathrm{C} \mu$ transcripts in the bone marrow of $68 \%$ of patients which proves that these cells could be the clonogenic origin of the tumor clone. However, no extensive study has been done on cases of biclonal plasma cell myeloma in order to identify what abnormality can be detected at the RNA level (Decaux et al. 2008).

Based on a study done by Decaux et al. (2008) on clinical and biological features of biclonal gammopathies review of 203 cases, it was reported that about $40 \%$ of the patients with biclonal gammopathies have been found to be symptomatic and most of them were more frequently associated with lymphoproliferative diseases rather than plasma cell myeloma (Chen et al. 2013). This is quite contradictory to our case in which the patient was asymtomatic with normal serum calcium level, normal renal profile and no lytic lesion seen on the skeletal survey which is typical presentation of smouldering myeloma.

In term of treatment response, Kyle et al. (1981) in his study on 57 cases of biclonal gammopathies showed that the response to therapy and survival were much the same as in patients with plasma cell myeloma with monoclonal protein in most of the cases. Nevertheless, there are cases of plasma cell myeloma with 
biclonal $\lg \mathrm{D}$ and $\lg \mathrm{M}$ reported showing disease aggressiveness and chemoresistant (Chen et al. 2013). In our case, although the patient was started on chemotherapy regime but eventually died due to neutropenic sepsis which is a main concern especially when using thalidomide for the treatment of frail patients (Palumbo et al. 2012).

\section{CONCLUSION}

We reported a rare case of plasma cell myeloma with a combination of $\lg \mathrm{G}$ lambda and IgA lambda biclonal gammopathy. Further extensive study on molecular events responsible for this exceptional combination may be helpful to determine their clonal origin, pathogenesis and may unfold whether they belong to a truly biclonal population or rather a single neoplastic clone.

\section{REFERENCES}

Al-Riyami, N., Al-Farsi, K., Al-Amrani, K., Al-Harrasi, S., Al-Huneini, M., Al-Kindi, S. 2015. Biclonal gammopathy in chronic lymphocytic leukemia: case report and review of the literature. Oman Med J 30(3): 216-8.

Banerjee, A., Pimpalgaonkar, K., Christy, A.L. 2016. A rare case of multiple myeloma with biclonal gammopathy. J Clin Diagn Res 10(12): BD03BD04.

Chen, Z.W., Kotsikogianni, I., Raval, J.S., Roth, C.G., Rollins-Raval, M.A. 2013. Biclonal IgD and IgM Plasma Cell Myeloma: A report of two cases and a literature review. Case Rep Hematol 2013: 293150.
Decaux, O., Leroy, H., lanotto, J., Ruelland, A., Guenet, L., Sebillot, M., Jego, P., \& Grosbois, B. 2008. Clinical and Biological Features of Biclonal Gammopathies. Review of 203 Cases. Blood 112(11): 5151.

Huppmann, A.R., Liu, M.L., Nava, V.E. 2010. Concurrent diagnoses of Hodgkin lymphoma and biclonal myeloma in the bone marrow. Ann Diagn Pathol 14(4): 268-72.

Kim, N.Y., Gong, S.J., Kim, J., Youn, S.M., Lee, J.A. 2011. Multiple myeloma with biclonal gammopathy accompanied by prostate cancer. Korean J Lab Med 31(4): 285-9.

Kumar, M.L., Salma, M., Bhulaxmi, P., Malathi, K., Abdullah, S.K. 2014. Biclonal Gammopathy of IgA Kappa variants - A Case Report. IJBR 5(10): 640-2.

Kyle, R.A., Robinson, R.A., Katzmann, J.A. 1981. The clinical aspects of biclonal gammopathies. Review of 57 cases. Am J Med 71(6): 999-1008.

Palumbo, A., Bladé, J., Boccadoro, M., Palladino, C., Davies, F., Dimopoulos, M., Dmoszynska, A., Einsele, H., Moreau, P., Sezer, O., Spencer, A., Sonneveld, P., San Miguel, J. 2012. How to Manage Neutropenia in Multiple Myeloma Clinical Lymphoma. Clin Lymphoma Myeloma Leuk 12(1): 5-11.

Reece, D.E., Vesole, D.H., Shrestha, S., Zhang, M.J., Pérez, W.S., Dispenzieri, A., Milone, G.A., Abidi, M., Atkins, H., Bashey, A., Bredeson, C.N., Boza, W.B., Freytes, C.O., Gale, R.P., Gajewski, J.L., Gibson, J., Hale, G.A., Kumar, S., Kyle, R.A., Lazarus, H.M., McCarthy, P.L., Pavlovsky, S., Roy, V., Weisdorf, D.J., Wiernik, P.H., Hari, P.N. 2010. Outcome of patients with IgD and IgM multiple myeloma undergoing autologous hematopoietic stem cell transplantation: a retrospective CIBMTR study. Clin Lymphoma Myeloma Leuk 10(6): 458-63.

Swerdlow, S.H., Campo, E., Harris, N.L., Jaffe, E.S., Pileri, S.A., Stein, H., Thiele, J., Vardiman, J.W. 2008. WHO Classification of Tumours of Haematopoietic and Lymphoid Tissues. 4th edition. Lyon: IARC Press; 200-13.

Received: 19 September 2016

Accepted: 26 May 2017 